\title{
As duas mortes do poeta
}

Sergio Miceli*

https://orcid.org/0000-0001-8989-0983

À memória de Maria Helena Arrigucci

Duas vezes se morre: Primeiro na carne, depois no nome. Manuel Bandeira, Versos de abertura de "Os nomes"1

O ensaio de Davi Arrigucci Jr. ([1990] 2009) a respeito da obra poética de Manuel Bandeira (1886-1968) se estriba em análises estilísticas que iluminam a substância dos termos com que o crítico condensa sua poética: humildade, paixão e morte. Não se trata de diagnoses formalistas; o autor mobiliza, em paralelo à inteligibilidade da matéria literária, referências históricas, tradições populares, aspectos folclóricos, plásticos, musicais, e toda sorte de materiais aptos a mediar dimensões insuspeitadas da lírica em foco. Os poemas foram decerto escolhidos no intento de restituir as experiências de vida transfiguradas pela alquimia da linguagem exercida por um mestre do ofício. A leitura magistral da obra de Bandeira não desgarra da preocupação reflexiva em torno do modernismo brasileiro, sem descurar da fortuna crítica precedente.

O ensaio sobre o poema "Maçẫ" (Petrópolis, 1938)2 propicia o introito bem urdido à persona autoral da "poética da humildade", atenta aos "pequeninos nadas" da vida prosaica e, nessa súmula, oferece ao leitor o retrato minimalista do poeta confinado

* Universidade de São Paulo, São Paulo, Brasil.

1. O poema consta do volume Opus 10, publicado por Bandeira em 1952.

2. De Estrela da vida inteira (Bandeira, 1966, p. 157). 
ao quarto modesto de solteiro, aos dezoito anos já tuberculoso (1904), acossado precocemente por duas mortes, a física e a social. Vale-se em seguida do "Poema só para Jaime Ovalle"3 no intuito de vasculhar o universo carioca de sociabilidade em que se movia Bandeira, outra vez por meio de um autorretrato, em que se misturam ansiedades, erotismo e ramerrão cotidiano. A menção ao músico e poeta Jaime Ovalle remete à boemia literária e musical na Lapa da década de 1920, dando protagonismo vicário à figura excêntrica e um tanto idealizada nessa roda de artistas, músicos e intelectuais. Destituído de obra pessoal, Ovalle sobreviveu na história intelectual como personagem quase ficcional, duplo mitológico no imaginário de Bandeira.

A segunda parte se inicia com a leitura compassiva do Itinerário de Pasárgada (Bandeira, 1954), narrativa memorialística na qual o poeta exalta a si mesmo como virtuose e pleiteia ser ajuizado apenas por critérios estéticos. A que se segue o refinado exercício de arqueologia crítica em torno do poema "Alumbramento" (Clavadel, $1913)^{4}$, rastreando, em versos da mocidade anteriores à estreia em livro, o enraizamento do artesão primoroso na tradição lírica europeia e brasileira.

A essa altura se reconhece a pegada sociológica do contribuinte, mas espero compensar o atrevimento pelo realce de passagens capazes de justificar o mote da morte social, tão pulsante na série de poemas analisados na terceira parte: "A morte em cena", "Profundamente", "Poema de finados" e "Boi morto". Embora tais composições mereçam do crítico atenção desigual, justificam em conjunto a leitura que puxa a brasa para o encosto determinista. Claro, o eventual proveito ou interesse analítico será logrado com base no imenso território expressivo já desbastado pelo crítico. Não fora a argúcia dos desvendamentos ou a liga de determinações misturadas, a arenga materialista ficaria sem chão.

A matéria de fundo nas quatro encenações fantasiosas remói a história de vida de Bandeira no decorrer das sucessivas perdas conducentes à morte social que está na raiz da reconversão do herdeiro raté em letrado apto a transmutar um destino de refúgio em voz sublimada. "Profundamente"5 evoca a festa de São João em momentos distintos - o menino de seis anos na casa-grande repleta, o adulto sofrido no quarto da casa de aluguel, na rua do Curvelo, em Santa Tereza -, em toada saudosa dos avós e dos empregados, prenúncio agourento das perdas que com efeito mudaram o

3. Poema publicado em Belo Belo, última parte, então inédita, do volume Poesias completas (Bandeira, 1948).

4. O poema consta do livro Carnaval, edição do autor, publicado em 1919, designando após o título o nome do sanatório suíço em que se internou, perto de Davos-Platz, em 1913. No espaço de seis anos, falecem a mãe (1916), a irmã (1918), o pai (1920) e o irmão (1922) do poeta.

5. Libertinagem (poemas de 1924 a 1930), em edição de quinhentos exemplares custeada pelo autor (Bandeira, 1930). 
rumo da vida dos pais, dos irmãos e do poeta. O narrador lírico encadeia o sono dos contemporâneos ao descanso perene dos mortos de sua infância, notação escapista da condição de orfandade que apressou a morte em vida do que ele poderia ter sido.

Em crônica de Flauta de papel, citada por Davi, o poeta parece recusar "o peso morto do passado", como se fosse possível firmar um partido de indeterminação. Mas logo se contradiz, ao admitir que o passado continua a existir como um presente, "uma enorme paisagem sem linhas de fuga, [...] sem perspectiva, onde todos os incidentes, os de ontem, os do ano passado, os de há cinco anos se apresentam no mesmo plano, como nos desenhos de criança" ${ }^{3}$. No arremate do mesmo parágrafo, o poeta faz meia-volta e expressa, sem enfeite, o estrondo que lhe causou a orfandade: "Meu pai morreu faz vinte e nove anos. Não me consolo: foi ontem. De vez em quando me assusto: faz trinta anos que tal coisa aconteceu!" (Ibidem). Apesar da peleja interna entre subterfúgios e assertivas, o Paganini do eufemismo, nem assim se desvencilha, queira ou não, das constrições objetivas que moldaram seu itinerário, a começar pela marcha forçada de entrega incondicional à carreira intelectual.

POEMA DE FINADOS

Amanhã que é dia dos mortos

Vai ao cemitério. Vai

E procura entre as sepulturas

A sepultura de meu pai.

Leva três rosas bem bonitas,

Ajoelha e reza uma oração.

Não pelo pai, mas pelo filho:

O filho tem mais precisão.

O que resta de mim na vida

É a amargura do que sofri.

Pois nada quero, nada espero.

E em verdade estou morto ali.

(Bandeira, 1930).

O "Poema de finados" evidencia os sentidos salientados por Davi - "antecipação da morte do próprio sujeito, identificação com seus mortos, [...] sensação de morte em vida, até mesmo de inumação em vida, ou ainda, ao contrário, [...] sentimento

6. Crônica "Variações sobre o passado", de Flauta de papel, 1957 (Bandeira, 1958, p. 294). 
de divisão do ser e de perda de si mesmo" (Arrigucci Jr., [1990] 2009, p. 228). Tais versos embutem ainda uma postura reflexiva, gaiata, despachada, acerto de contas fora de prazo com a figura paterna, cuja morte, muito mais do que a doença, truncou quaisquer alternativas de carreira masculina. $O$ poeta se viu alijado da posição social que lhe fora destinada. O filho que se enxerga morto em vida "tem mais precisão" da reza, por força da mutilação devastadora motivada pelo sumiço do pai. Em ordem contrária ao que sugerem os versos do poema "Os nomes", referidos na epígrafe, Bandeira estava ciente das circunstâncias em que sucedeu a morte social de suas expectativas como herdeiro presuntivo das posições e regalias a que faria jus não fossem a doença e a subsequente orfandade. Quem está morto ali é o beneficiário do futuro de classe transtornado pela falência familiar.

BOI MORTO

Como em turvas águas de enchente,

Me sinto a meio submergido

Entre destroços do presente

Dividido, subdividido,

Onde rola enorme, o boi morto.

Boi morto, boi morto, boi morto.

Árvores da paisagem calma,

Convosco - altas, tão marginais! -

Fica a alma, a atônita alma,

Atônita para jamais.

Que o corpo, esse vai com o boi morto,

Boi morto, boi morto, boi morto.

Boi morto, boi descomedido,

Boi espantosamente, boi

Morto, sem forma ou sentido

Ou significado. O que foi

Ninguém sabe. Agora é boi morto,

Boi morto, boi morto, boi morto.

(Bandeira, 1952). 
"Profundamente" e "Boi morto" constam do volume 50 Poemas escolbidos pelo autor, na prestigiosa série "Os Cadernos de Cultura" com chancela oficial (Bandeira, 1959), senha relevante do juízo de valor do poeta sobre o conjunto da obra. Bandeira se elegeu, em 29 de agosto de 1940, durante o Estado Novo, para a Academia Brasileira de Letras, vencendo Berilo Neves (sete votos), Júlio Nogueira (cinco votos) Oswald de Andrade (um voto) e Basílio de Magalhães (um voto), um ano antes da eleição de Getúlio Vargas como acadêmico. Ambos venceram em primeiro escrutínio, Bandeira com 21 votos, Vargas com 33 sufrágios, sem concorrente e apenas um voto em branco $^{7}$. Nessa quadra da vida, o poeta já passara por algumas incursões de militância política: havia sido o primeiro presidente da Associação Brasileira de Escritores, fundada em 1942, entidade de resistência à ditadura a que continuou ligado até 1949 e da qual se afastaria por discordâncias com o grupo comunista. Após a queda de Vargas, integrou a Esquerda Democrática a pedido de Sergio Buarque de Holanda e candidatou-se a deputado federal pelo Partido Socialista Brasileiro. Sempre que indagado acerca de tais envolvimentos, Bandeira costumava dizer que sucumbira ao assédio de amigos.

Tais informações me parecem indispensáveis à compreensão do tumulto pessoal e profissional aludido de banda nesse poema-chave da maturidade. Aí a reminiscência de infância vai de cambulhada com as inquietações e os questionamentos do escritor já consagrado. A datação do poema ajuda a deslindar o subtexto. "Boi morto" liga as pontas de sua trajetória: de um lado, a infância longínqua que comprime numa tomada de cinema o som e a fúria do mundo social; de outro, as láureas de reconhecimento que desaguaram no mau hálito existencial adquirido em tempos de exceção.

O estudo magnífico do "Boi morto" constitui um dos pontos altos do livro de Davi Arrigucci Jr., como que imantando as dimensões mobilizadas pelo intérprete: a memória do passado, o cenário da infância, a libido, o desconcerto do presente, as contingências do trabalho intelectual, a fragilidade da sublimação poética, o arrastão do boi morto investido pelos sentimentos projetivos do narrador. As razões invocadas por Davi e desemaranhadas pela análise - desde a cifra do título, passando pelo enovelamento entre a cena descrita e a situação atual do sujeito, até o parágrafo de fecho que desvela os paralelos entre o boi morto e o Eu lírico, ambos a caminho da destruição - dão conta do enigma e surpreendem o leitor numa sucessão de relances e ligamentos apaixonantes. Não obstante, gostaria de retomar certas passagens do

7. Ver Fernão Neves (pseudônimo de Fernando Nery, diretor da Secretaria da ABL), A Academia Brasileira de Letras, notas e documentos para a sua história (1896-1940), 1940, p. 141. O livro foi retirado de circulação por decisão do plenário da ABL em função de críticas formuladas pelos acadêmicos Ribeiro Couto e Clementino Fraga, sob a alegação de que o texto continha informações detratoras sobre a ABL e alguns acadêmicos. Consultar ainda Carvalho (2009, p. 15). 
poema e da análise, pretexto para dizer com minhas palavras o que está tão bem equacionado pelo crítico.

Primeiro, compartilho a leitura da imagem do "boi morto" como elemento de fixação para o qual convergem desencontros e emoções do narrador. Tudo se passa como se o leitor fosse incitado a enxergar no animal à deriva, arrastado pela correnteza, o símile do cadáver do narrador. Eis o efeito subliminar responsável pela força de convicção do poema: de pronto o leitor torna-se cúmplice ao se identificar com o poeta desnorteado. O “boi morto”, o Eu lírico, todos nós atropelados pela enxurrada da vida, apesar do refresco por vezes sentido na marginal da sublimação. Nas palavras de Davi, "seguindo o olhar que, por sua vez, acompanha o boi morto e, através deste, o curso do rio e do ritmo, cujo movimento imprime um repetido rodopio a cada divisão estrófica [...] acrescentando um elemento de ameaça e vertigem a cada final de estrofe" (Arrigucci Jr., [1990] 2009, p. 239).

$\mathrm{Na}$ segunda estrofe, dois elementos chamam atenção e, salvo engano, contribuem de modo enviesado ao esclarecimento da atmosfera de interregno espiritual aí sugerido. O vocativo "convosco" é um termo de oração religiosa que conclama a comunhão dos fiéis, dos circunstantes, dos nossos semelhantes, para o bálsamo do amparo espiritual, de apaziguamento da alma. Prestes a encerrar a missa, o sacerdote se dirige aos crentes, "a paz esteja convosco". Dito de outro modo, essa estrofe do discurso altaneiro, o qual se revela incapaz de trazer consolo à desdita terrena, reforça a inapelável sentença condenatória do corpo. As árvores que se lançam para o alto, para o céu, domínio do elevado, do mágico, da epifania, do alumbramento - termos de resistência ao desencantamento do mundo -, não logram sustar a passagem do tempo. As ilusões e os devaneios do espírito são engolfados pela avalanche temporal que vai minando as energias do desejo carnal. A alma ficou no recesso do assombro, imagem defensiva a que logo se sobrepõe a destruição do corpo. O clima conventual dos quatro primeiros versos da estrofe é contraditado pela via crucis do corpo, o nosso e o do boi, na rebentação do rio, da existência.

A última estrofe acelera e intensifica a simbiose do poeta narrador com o boi morto, infundindo atributos projetivos no receptáculo que, por transe, transmutam o boi em homem, em sujeito também objeto de desgaste irreversível, presa do desarranjo, da finitude. É descomedido o boi ou a intromissão do poeta redunda em fantasmagoria? O quão exorbitante é a insistência em confundir o boi com o homem, o boi consigo? "Boi espantosamente" homem, eis a analogia mais desestabilizadora do enunciado. O poeta leva ao paroxismo o baralhamento, a permuta de status e de condição, impregnando o boi com propriedades humanas. Os versos oscilam entre a insinuação de anamorfose, o boi monstrengo e superlativo, e os acenos de antropomorfismo. 
O $M$ maiúsculo na cesura entre boi e Morto, na passagem do segundo para o terceiro verso, dá concretude ao Eu lírico tal como fora qualificado na estrofe inicial, em meio a destroços do presente, "Dividido, subdividido", quiçá esquartejado. Esse arranjo voluntarioso aparta o boi do sujeito humano, ora finado e desvalido, fazendo do Morto em letra graúda o indício de autonomia perante o boi. O truque sintático oferece ao poeta o ensejo de se enxergar como um cadáver qualquer, "sem forma ou sentido ou significado". Davi sentencia ao final: "a imagem parece encarnar ainda um terror primitivo ou infantil diante da morte como a impressão sinistra de uma cena de pesadelo, onde o boi morto é agora uma espécie de duplo do próprio Eu minado pela destruição" (Idem, p. 253).

Referências Bibliográficas

ArrigucCi JR., Davi. ([1990] 2009), Humildade, paixão e morte, a poesia de Manuel Bandeira. 2 ed. São Paulo, Companhia das Letras.

Bandeira, Manuel. (1919), Carnaval. Rio de Janeiro, Edição do Autor.

Bandeira, Manuel. (1930), Libertinagem. Rio de Janeiro, Pongetti.

Bandeira, Manuel. (1948), Poesias completas. Rio de Janeiro, CEB.

Bandeira, Manuel. (1952), Opus 10. Rio de Janeiro, Edições Hipocampo.

Bandeira, Manuel. (1954), Itinerário de Pasárgada, Rio de Janeiro, Jornal de Letras.

Bandeira, Manuel. (1958), Flauta de papel. Rio de Janeiro, Alvorada, 1957. In: Manuel Bandeira poesia e prosa, vol. II. Rio Janeiro, Aguilar.

Bandeira, Manuel. (1959), 50 poemas escolbidos pelo autor. Rio de Janeiro, Ministério da Educação e Cultura ("Os Cadernos de Cultura", vol. 77).

Bandeira, Manuel. (1966), Estrela da vida inteira. Rio de Janeiro, José Olympio.

Carvalho, José Murilo de (org.). (2009), A Academia Brasileira de Letras, subsídios para sua história (1940-2008). Rio de Janeiro, Academia Brasileira de Letras.

Neves, Fernão [pseudônimo de Fernando Nery]. (1940), A Academia Brasileira de Letras, notas e documentos para a sua história (1896-1940). Prefácio de Afrânio Peixoto. Rio de Janeiro, Publicações da Academia Brasileira. 


\section{Resumo}

\section{As duas mortes do poeta}

Escrutínio da análise da poesia de Manuel Bandeira em livro clássico de Davi Arrigucci Jr., com ênfase em poemas que mesclam materiais da experiência pessoal a circunstâncias políticas incidentes sobre a trajetória e a visão de mundo do escritor.

Palavras-chave: Experiência social; Condicionantes políticos; Moderna poesia brasileira e crítica literária.

\section{Abstract}

\section{The poet dies twice}

Brief appraisal of Davi Arrigucci Jr. classic book on Manuel Bandeira’s poetry, emphasizing poemas which entangle materials from personal experience and political circumstances related to the writer's career and worldview.

Keywords: Social experience; Political constraints; Modern Brazilian poetry and literary criticism.

Texto recebido em 6/8/2020 e aprovado em 24/8/2020.

DOI: $10.11606 / 0103-2070 . t s .2020 .173350$.

Sergio Miceli é professor titular de sociologia na Universidade de São Paulo. E-mail: zaem@ usp.br.

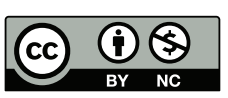

